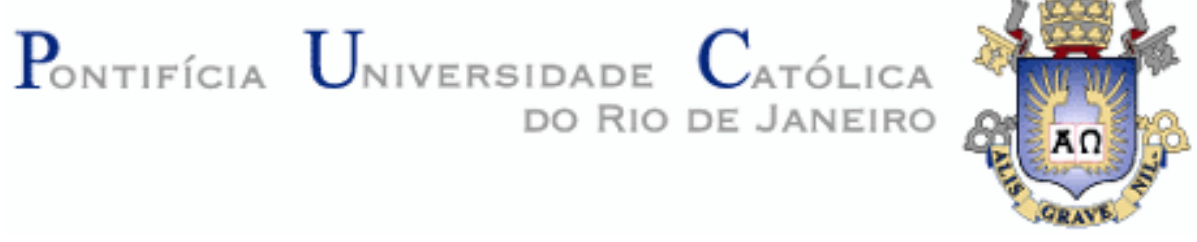

Carolina Lyrio Tenorio-Daussat

Peptide-labeling with metals using MS detection and optimization of metalloprotein extraction procedures in biological samples with proteomic purposes

TESE DE DOUTORADO

Thesis presented to the Programa de Pós-graduação em Química of the Departamento de Química, PUCRio as partial fulfillment of the requirements for the degree of Doutor em Química.

Advisors: Prof. Tatiana D. Saint'Pierre Prof. Dirk Schaumloffel Co-Advisor: Dr. Rachel Ann Hauser-Davis

Rio de Janeiro March 2014 
Carolina Lyrio Tenorio-Daussat

Peptide-labeling with metals using MS detection and optimization of metalloprotein extraction procedures in biological samples with proteomic purposes

Thesis presented to the Programa de Pós-Graduação em Química of the Departamento de Química do Centro Técnico Científico da PUC-Rio, as partial fulfilment of the requeriments for the degree of Doutor em Química.

Prof. Tatiana D. Saint'Pierre Thesis Advisor - Departament of Chemistry PUC-Rio

Prof. Dirk Schaumloffel Thesis Advisor - UPPA

Dr. Rachel Ann Hauser-Davis Co-Advisor - PUC-Rio

Prof. José Marcus de Oliveira Godoy Departament of Chemistry PUC-Rio

Prof. Josino Costa Moreira FIOCRUZ

Prof. Roberta Lorença Ziolli UNIRIO

Prof. Ricardo Erthal Santelli UFRJ

Prof. José Eugenio Leal Coordinator of the Centro Técnico Científico - PUC-Rio 
All rights reserved.

\section{Carolina Lyrio Tenorio-Daussat}

The author graduated in Chemistry at UFES (Federal University of Espirito Santo) in 2007. She obtained a Master degree in Analytical Chemistry at PUC-Rio in 2010.

Bibliographic data

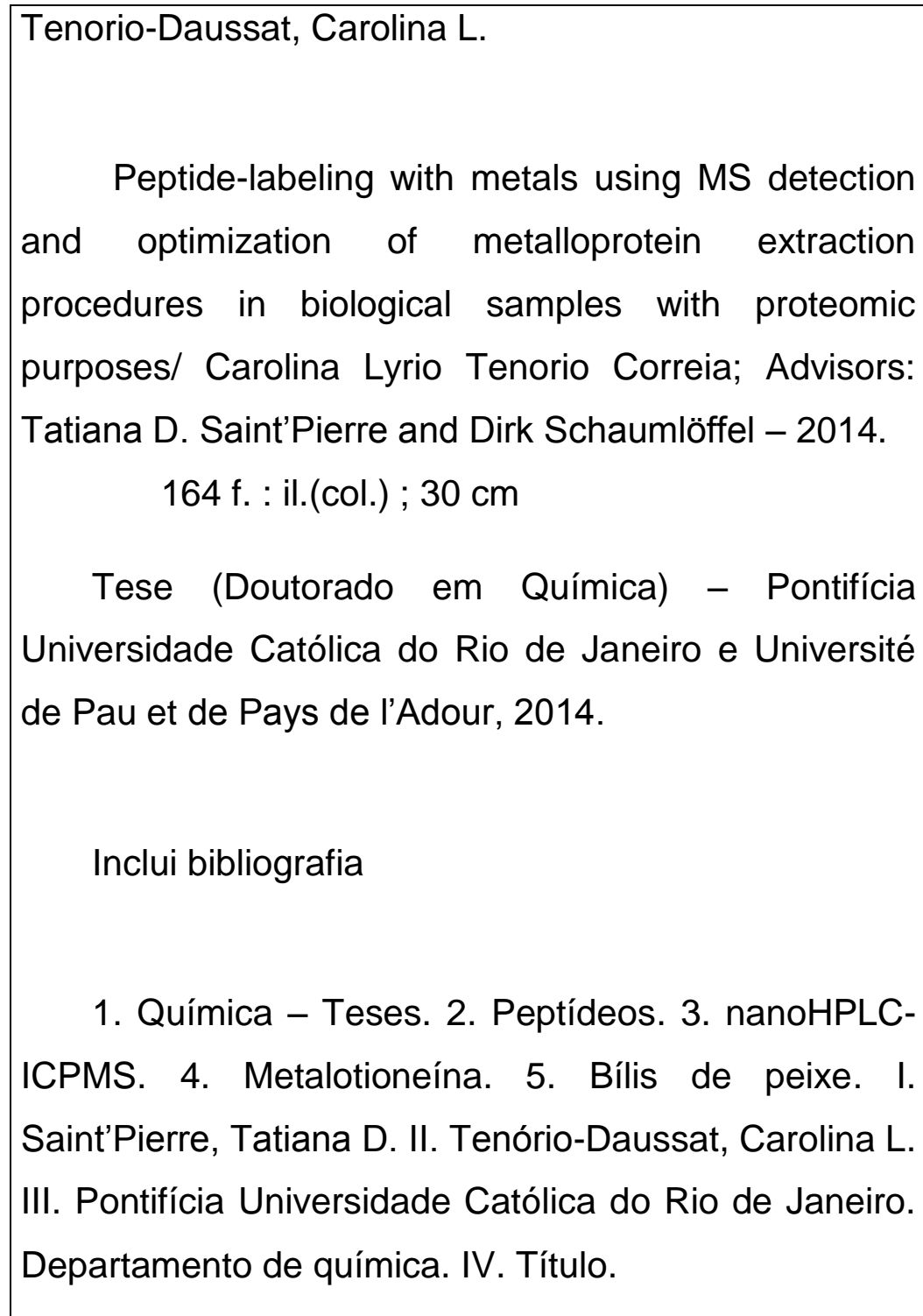


Para Deus.

Para meus pais, Claudio e Tania, que me deram vida e força.

Para Boris, meu marido, meu apoio, minha metade. 


\section{Acknowledgments}

I would like to thank the people who directly or indirectly helped me start and continue this work.

To God, who put me on the path of light, moving increasingly forward.

To CNPq, FAPERJ, CNRS, UPPA and PUC-Rio, for the aid, without which this work could not have been accomplished.

To my late lamented advisor, Reinaldo Calixto de Campos, for every teaching (academic and life); and for the example.

To my advisor, Tatiana D. Saint'Pierre, for welcoming me with satisfaction in her group.

My advisor, Dirk Schaumlöffel, for the grand welcome in a country completely unknown to me.

To my lab partner, Angela Holste, for all the help at work.

To my co-advisor, Rachel Hauser-Davis, for her dedication, patience and all the help with English.

To the professors Andreas Tholey, Marco Aurélio Zezzi Arruda and Wanderson Romão, for the analysis assigned in their respective laboratories.

To everyone in the "LABSPECTRO", specially Rafael Chavez, Marcia Carolina and Julia Lemos.

To Fátima, a super secretary.

To all friends from PUC-Rio.

To all teachers for the patience in the review and the great contribution to my work through their suggestions.

The whole my family, even from afar is always present and cheering for me.

À la fin, mais ce ne pas moins important, je remercie mon mari, Boris, par la présence, la participation et la patience, surtout en ce moment de la finalisation de ma thèse.

To all of you a very special way contributed to the success of my 4 years of work, my many thanks! 


\section{Abstract}

Tenorio-Daussat, Carolina L.; Schaumlöffel, Dirk; Saint'Pierre, Tatiana D. Peptide-labeling with metals using MS detection and optimization of metalloprotein extraction procedures in biological samples with proteomic purposes. Rio de Janeiro, 2014, 164 p. PhD Thesis Departamento de Química, Pontifícia Universidade Católica do Rio de Janeiro and Institut des Sciences Analytiques et de Physico-Chimie pour L'Environnement et les Matériaux (IPREM), Université de Pau et des Pays de l'Adour.

This $\mathrm{PhD}$ thesis is a Cotutelle between the PUC-Rio (Brazil) and the UPPA (France).

This work developed a new method for the identification and quantification of peptides, by optimizing some of the available strategies suitable for labeling peptides with lanthanide metals with subsequent separation by nano-HPLC with UV detection, matrixassisted laser desorption ionization-mass spectrometry (MALDI MS). First, peptides were labeled with the three different lanthanide metals using a functional DOTA-based reagent. The results demonstrate that the derivatization reaction using the chelating reagent DOTA-NHS-ester was effective for single peptides and peptide mixtures, verified from the $\mathrm{m} / \mathrm{z}$ relation obtained by MALDI MS. In parallel, environmental analyses were conducted, by performing the standardization of metalloprotein purification in fish bile, since this matrix has been reported as a biomarker for environmental metal contamination. Different procedures and reducing agents were applied to purify MT isolated from fish (Oreochromis niloticus) bile and liver. Spectrophotometrical analyses were used to quantify the resulting MT samples, and SDS-PAGE gels were used to qualitatively assess the different procedure results. A response surface methodology was applied for bile samples. In an environmental context, biliary MT was lower than liver MT, and, bile MT seems to be more adequate in environmental monitoring scopes.

\section{Keywords}

Peptides; nano-HPLC-ICP-MS; MALDI MS; SDS-PAGE; MT; fish bile. 


\section{Resumé}

Tenorio-Daussat, Carolina L.; Schaumlöffel, Dirk; Saint'Pierre, Tatiana D.

Le marquage des peptides avec des métaux et détection par MS et l'optimisation des procédures de l'extraction de métalloprotéines dans les échantillons biologiques à des fins de protéomique. Rio de Janeiro, 2014, 164 p. Thèse de Doctorat - Departamento de Química, Pontifícia Universidade Católica do Rio de Janeiro et Institut des Sciences Analytiques et Physico-Chimie pour l'Énvironnement et les Matériaux (IPREM), Université de Pau et des Pays de l'Adour.

Cette thèse de doctorat est résultat d'une cotutelle entre la PUC-Rio (Brésil) et l'UPPA (France).

Ce travail a développé une nouvelle méthode pour l'identification et la quantification des peptides, par l'optimisation de certaines stratégies disponibles appropriées pour le marquage des peptides avec des métaux lanthanide, une séparation par nano-HPLC et détection UV, et suivi par MALDI MS. Tout d'abord, les peptides ont été marqués avec les trois métaux lanthanides différents et un réactif fonctionnel - DOTA. Les résultats montrent que la réaction de transformation en dérivé à l'aide du réactif chélateur DOTA-NHS-ester a été efficace pour des peptides individuels et des mélanges de peptides, vérifiées à partir de la relation $\mathrm{m} / \mathrm{z}$ obtenue par MALDI MS. En parallèle, nous avons effectué l'optimisation pour la purification de métalloprotéine dans la bile de poisson, qui est signalée entant que biomarqueurs de contamination métallique de l'environnement. Des procédures différentes et les agents réduisant ont été apliqués pour purifier les MT isolées de la bile et du foie des poissons (Oreochromis niloticus). Des analyses spectrophotométriques ont été utilisées pour quantifier les échantillons de MT, et le gel SDS-PAGE a été utilisé pour évaluer qualitativement les différents résultats de la procédure. Chaque procédure a en suíte été évaluée statistiquement, une méhtode des surfaces de réponse a été appliquée. Les MT de la bile semblent être plus adéquate pour la surveillance de l'environnement en ce qui concerne l'exposition récente à des xénobiotiques qui peuvent influer sur l'expression protéomique et metalloproteomique de cette matrice biologique.

\section{Mots clefs}

Peptides; nano-HPLC-ICP-MS; MALDI MS; SDS-PAGE; MT; bile de poisson. 


\section{Resumo}

Tenorio-Daussat, Carolina L.; Schaumlöffel, Dirk; Saint'Pierre, Tatiana D. Marcação de peptídeos com metais usando detecção por MS e otimização de procedimentos de extração de metaloproteínas em amostras biológicas com propósitos proteômicos. Rio de Janeiro, 2014, 164 p. Tese de Doutorado - Departamento de Química, Pontifícia Universidade Católica do Rio de Janeiro e Instituto de Ciências Analíticas e Físico-Química Ambiental e Materiais (IPREM), Universidade de Pau e dos Países do Adour.

Esta tese de doutorado é resultado de uma cotutela entre a PUC-Rio (Brasil) e a UPPA (França).

Método de identificação e quantificação de peptídeos, através da otimização de estratégias para a marcação de peptídeos com metais e subsequente separação por nanoHPLC-UV, MALDI MS. Primeiramente, peptídeos foram marcados com 3 diferentes metais lantanídeos usando um reagente funcional NHS-DOTA. Os resultados demonstraram que a reação de derivatização usando o reagente quelante DOTA foi eficiente para peptídeos simples e misturas dos mesmos, verificada através do MALDI MS a partir da relação m/z. Em paralelo, análises ambientais foram realizadas pela otimização de um procedimento de extração de metalotioneína em bílis de peixe, uma vez que esta matriz tem sido reportada como um biomarcador ambiental de contaminação por metal. Diferentes procedimentos e agentes de redução foram aplicadas para a extração de metalotioneína em bílis e fígado de peixe (Oreochromis niloticus. Análises espectrofotométricas foram realizadas a fim de quantificar os extratos de MT, e gel SDSPAGE foi usado para avaliação qualitativa dos diferentes procedimentos usados. Cada procedimento foi avaliado estatisticamente. Metodologia de superfície de resposta foi aplicada para amostras de bílis, a fim de avaliar a resposta desta matriz. Em um contexto ambiental, concentrações de MT biliar foi mais baixa que MT do fígado, no entanto, a primeira mostrou-se mais adequada para um monitoramento ambiental.

\section{Palavras-chave}

Peptídeos; nano-HPLC-ICP-MS; MALDI MS; SDS-PAGE; MT; bílis de peixe. 


\section{Summary}

$\begin{array}{ll}\text { Contextualization } & 21\end{array}$

1. Introduction 23

1.1. Proteomics and metallomics 23

1.2. Protein and metalloprotein biomarkers applied to environmental biomonitoring studies 25

1.2.1. Biomarkers 25

1.2.2. Biomolecules in fish used as biomarkers in an environmental context 28

1.2.3. Proteomics in fish biomarker identification $\quad 30$

1.2.4. Bile as a bioindicator matrix 32

1.3. Analytical techniques used in proteomic and metallomic studies 33

1.3.1. Sample preparation for proteomic and metallomic analyses 34

1.3.2. Analytical methods used in protein quantification

and characterization 36

1.3.2.1. Total metal determination by ICP-MS and

protein-bound metal determination by hyphenated systems

coupled to ICP-MS detection $\quad 40$

1.3.2.2. Ultraviolet-visible molecular absorption and its applications in proteomics 42

1.3.2.3. One- and two-dimensional gel electrophoresis 45

1.3.2.4. Protein identification by mass spectrometry after separation by gel electrophoresis 
1.3.2.7. Approaches to protein identification after MS analyses databases and bioinformatics

1.3.2.8. Alternative methods for protein characterization

1.3.2.8.1. Fourier-Transform infrared (FR-IR) vibrational spectroscopy in qualitative protein characterization

2. Objectives and study justifications $\quad 58$

2.1. PART I: Peptide derivatization and complexation with metals 58

2.1.2. General objective 58

2.1.2.1. Specific objectives $\quad 58$

2.2. PART II: Optimization of metalloprotein extraction procedures from environmental samples $\quad 59$

2.2.1. General objective $\quad 59$

2.2.1.2. Specific objectives $\quad 59$

$\begin{array}{ll}\text { 3. Methodology } & 60\end{array}$

3.1. PART I: Peptide derivatization and complexation with metals 60

3.1.1. Materials $\quad 60$

$\begin{array}{ll}\text { 3.1.2. Sample preparation } & 60\end{array}$

$\begin{array}{ll}\text { 3.1.2.1. Labeling procedure } & 61\end{array}$

3.1.2.2. Sample preparation for MALDI TOF MS 62

3.1.3. Peptide separation by nano-Ion Pair-Reverse Phase-HPLC (nano-IP-RP-HPLC) 63

3.1.4. Peptide analysis by MALDI-TOF-MS 63

3.1.5. Peptide analysis by nano-HPLC-ICP-MS 65

3.2. PART II: Optimization of metalloprotein extraction procedures in environmental samples 
3.2.1.1. Environmental samples for the optimization of the metalloprotein extraction procedure

3.2.1.2. Laboratory exposure to metals

3.2.2. Metallothionein (MT) purification from Tilapia liver and bile samples

3.2.3. Metallothionein quantification by Ellman's assay 72

$\begin{array}{ll}\text { 3.2.4. Figures of merit } & 73\end{array}$

3.2.5. Total protein quantification 73

3.2.6. $1 \mathrm{D}$ and 2D gel electrophoresis 73

3.2.7. Gel staining after electrophoresis $\quad 75$

3.2.7.1. Coomassie blue G-250 staining 75

3.2.7.2. Silver nitrate staining 76

3.2.8. Gel scanning for image analysis 76

3.2.9. Tryptic digestion of gel protein spots for subsequent mass $\begin{array}{ll}\text { spectrometry analysis } & 76\end{array}$

$\begin{array}{ll}\text { 3.2.10. Mass spectrometry analyses } & 77\end{array}$

$\begin{array}{ll}\text { 3.2.10.1. MALDI-MS } & 77\end{array}$

$\begin{array}{ll}\text { 3.2.10.2. } \mathrm{nESI}-\mathrm{QTOF} \mathrm{MS} / \mathrm{MS} & 78\end{array}$

$\begin{array}{ll}\text { 3.2.11. Database research and bioinformatics } & 78\end{array}$

3.2.12. Sample preparation for metal determination by ICP-MS 79

3.2.13. SEC-HPLC-ICP-MS analyses 79

3.2.14. Fourier Transform vibrational spectroscopy in the infrared region (FT-IR) analyses - Qualitative clean-up effects of bile and liver samples $\quad 81$

$\begin{array}{ll}\text { 3.2.15. Statistical analyses } & 81\end{array}$

4. Results and Discussion 83

4.1. PART I: Peptide derivatization and complexation with metals 83

4.1.1. Peptide analysis by nano-HPLC-ICP-MS 90 
4.2. PART II: Optimization of metalloprotein extraction procedures from environmental samples

4.2.1. Spectrophotometric analyses 93

4.2.2. Response surface methodology for bile samples 100

4.3. SDS-PAGE analysis 102

4.3.1. 1D-SDS-PAGE 102

$\begin{array}{lr}\text { 4.3.2. 2D-SDS-PAGE } & 106\end{array}$

$\begin{array}{ll}\text { 4.4. Total protein quantification } & 108\end{array}$

$\begin{array}{lc}\text { 4.4.1. Commercial fish samples } & 108\end{array}$

4.5. Mass spectrometry analyses 110

4.6. SEC-HPLC-ICP-MS analyses 113

4.7. Statistical analyses for the laboratory fish exposures 120

4.7.1. Spearman correlations and Artifical Neural Networks (ANN) 120

4.8. Fourier Transform vibrational spectroscopy in the infrared region (FT-IR) analyses - Qualitative clean-up effects in bile and liver samples

5. Conclusions 128

5.1. PART I: Peptide derivatization and complexation with metals 128

5.2. PART II: Optimization of metalloprotein extraction procedures from environmental samples

5.2.1. Optimization with commercial fish 129

5.2.2. Analyses of the laboratory-exposed fish 130

$\begin{array}{lr}\text { 5.2. Future Prospects } & 132\end{array}$

6. References 


\title{
Acronyms List
}

\author{
Sodium dodecyl sulphate polyacrylamide gel electrophoresis \\ 1D SDS PAGE \\ in 1 dimension \\ Sodium dodecyl sulphate polyacrylamide gel electrophoresis \\ 2D SDS PAGE \\ in 2 dimensions \\ ACN \\ Acetronitrile \\ BSA \\ Bovine serum albumin \\ CE \\ Capillary electrophoresis \\ DMSO \\ Dimethyl sulfoxide \\ DNA \\ Deoxyribonucleic acid \\ DOE \\ Design of experiments \\ DOTA \\ 1,4,7,10-tetraazacyclodode- cane-1,4,7,10-tetraacetic acid \\ DTNB \\ 5-(3-Carboxy-4-nitrophenyl)disulfanyl-2-nitrobenzoic acid \\ DTPA \\ Diethylene triamine pentaacetic acid \\ DTPAA \\ DTT \\ Diethylenetriaminepentaacetic acid anhydride \\ Dithiothreitol \\ EDTA \\ Ethylenediamine tetraacetic acid \\ ESI \\ Electrospray ionization \\ FIA \\ Flow injection analysis \\ FT-ICR \\ FourrierTransform Ion Cyclotron Resonance \\ FT-IR \\ Fourrier Transform Infra-red \\ GSH \\ Glutathione \\ HFBA \\ ICP-MS \\ Heptafluorobutyric acid \\ Inductively coupled plasma mass spectrometry \\ MAL DOTA \\ Maleimidocysteineamido-DOTA \\ MALDI TOF MS \\ Matrix-assisted laser desorption-ionization time-of-flight \\ mass spectrometry \\ MMTS \\ S-methyl methanethiosulfonate \\ MT \\ Metalothionein \\ MW \\ Mass Weigth
}




\begin{tabular}{|c|c|}
\hline NANO HPLC & Nano High Performance/Pressure Liquid Chromatography \\
\hline NHS DOTA & N-terminus amino groups DOTA \\
\hline PES & Protein Express Signature \\
\hline RNA & Ribonucleic acid \\
\hline TCEP & Tris(2-carboxyethyl)phosphine \\
\hline TEAA & Triethylammonium acetate \\
\hline TFA & Trifluoroethanoic acid \\
\hline UV-VIS & Ultraviolet-visible \\
\hline$\alpha-C H C A$ & a-cyano-4-hydroxycinnamic acid \\
\hline
\end{tabular}




\section{List of figures}

Figure 1. Scheme of the levels of responses of biological systems. Adapted from Bayne (1985)

Figure 2. Scheme of experimental workflow for advanced mass spectrometry-based proteomics. Adapted from Kozuka-Hata (2013)

Figure 3. Hyphenated systems using ICP-MS detection,

Figure 4. Scheme of protein modification with SDS in gel electrophoresis

Figure 5. Schematic example of protein bands separation by 1D electrophoresis where each trace in numerical columns represent protein bands of decreasing molecular weight

Figure 6. Schematic example of protein separation by

two-dimensional gel electrophoresis, after the isoelectric focusing

Figure 7. MALDI-MS scheme

Figure 8. Schematic representation of the operating principle of a MALDI-TOF

Figure 9. Ion formation in ESI

Figure 10. Structure of the DOTA derivatization reagent with the NHS-ester function for amine-specific (highlighted) labelling

Figure 11. Amino acid lysine $(\mathrm{K})$ with its 2 free amino groups

Figure 12. Preconcentration and sample elution by nano-HPLC

Figure 13. Eluent gradient for peptide mixture separation.

Eluent A: $0.05 \%$ aqueous TFA. Eluent B: $0.04 \%$ TFA in $80 \%$ ACN:

$20 \%$ deionized water (v:v) 
Figure 14. Color-forming reaction of Ellman's reagent

with sulfhydryl groups

Figure 15. Peptides S34 and T1 identified in the mixture labelled

solution (S34, S35, S36, M6, and T1) with Lu-, Tm- and

Ho-NHS-DOTA

84

Figure 16. Peptides S36 (a) and T1 (b), respectively, with Lu-,

Ho- and Tm-NHS-DOTA, eluted separately by nano-LC UV

84

Figure 17. Nano-HPLC UV separation of the single peptides

a (S34), b (S36) and c (T1), respectively, using element Tm for

the complexation

85

Figure 18. Peptide mixture (S34, S36 and T1) NHS-DOTA complexed

with Tm and separated by nano-HPLC UV

86

Figure 19. Cytochrome C Tm-DOTA-NHS-ester separation

nano-HPLC UV

88

Figure 20. Tm-NHS-DOTA mixture peptide (S34, S36 and T1)

pre-washing graph

89

Figure 21. Tm NHS-DOTA-labeled peptide Hy analyzed with

HFBA (blue) and with TFA (pink) in the loading buffer

90

Figure 22. Analytical curves for metallothionein quantification:

(匹) GSH standards, I= $0.0005 \mathrm{C}, \mathrm{R}^{2}=0.9943$.

$(\bullet)$ MT standard addition in bile samples,

$I=0.0005 C+0.3167, R^{2}=0.9864$

92

Figure 23. Metallothionein concentrations in bile and in liver

(expressed in $\mu \mathrm{mol} \mathrm{L^{-1 }}$ ) for each of the tested purification

procedures and reagents

Figure 24. MT concentrations in bile (a) and in liver (b)

at different water bath temperature conditions

Figure 25. Concentration of MT in bile (a)

and in liver (b) at different centrifugation times 
Figure 26. Reagent box-plot chart data after $4^{3}$ multivariate

statistical analysis with TCEP, DTT and $\beta$-mercaptoethanol

Figure 27. Pareto Chart of Standardized Effects

regarding the studied factors for bile samples

Figure 28. Response surface charts for each of the studied factors for tilapia bile MT samples after $4^{3}$ multivariate statistical analysis

Figure 29. Qualitative SDS-PAGE gels for bile samples using the different extraction procedures and reagents analyzed in the present study

Figure 30. Qualitative SDS-PAGE gels for liver samples using the different extraction procedures and reagents analyzed in the present study

Figure 31. 2D Gels of an MT extracted bile sample - protocol B (60 min, $70{ }^{\circ} \mathrm{C}, 30 \mathrm{~min}$ ) and reagents: DTT (a)

b-mercaptoethanol (b) and TCEP (c)

Figure 32. Box plot - measurement of total protein in bile (a) and liver (b)

Figure 33. MALDI (+)- FT-ICR MS spectra of the 2D trypisinized MT-B

Figure 34. Standards used for column calibration in the SEC-HPLC-ICP-MS analyses

Figure 35. SEC-HPLC-UV-ICP-MS samples and MT-I standard for bile extracts

Figure 36. SEC-HPLC-UV-ICP-MS fish bile samples and MT-I standard for different extraction time and the same temperature

Figure 37. SEC-HPLC-UV-ICP-MS samples and MT-I standard for liver extracts

Figure 38: Architecture of ANN for classification as to metal 
exposure. (a, b and c) in bile samples, and (d, e and f) in liver samples

Figure 39. Infrared spectrum (a) crude liver, (b) purified liver and (c) delipidized liver; and on the right side of the figure, the deconvolution in the $1200-980 \mathrm{~cm}^{-1}$ region 


\section{List of tables}

Table 1. Main protein staining methods after one- or two-dimensional gel electrophoresis

Table 2. Instrumental parameters of ICP-MS

63

Table 3. Concentrations of the solutions used in the laboratory exposure experiment according to the maximum permitted concentrations allowed by CONAMA Resolution 357 |(2005)

Table 4. Description of each metallothionein purification procedure applied in the present study, with the first centrifugation step, the temperature and second centrifugation step indicated

Table 5. Description of metallothionein purification procedure B applied in the second step of this study, with the first and second centrifugation steps fixed

Table 6. Description of metallothionein purification procedure applied in the third step of this study, with the temperature step fixed

Table 7. Description of each different metallothionein reducing agent in conjunction with the different purification procedures conducted in the present study after a $4^{3}$ multivariate statistical analysis

Table 8. Instrumental operating SEC-HPLC-ICP-MS conditions

Table 9. Peptides derivatized with NHS-DOTA and their monoisotopic $\mathrm{m} / \mathrm{z}$ values (derivatization and metal-lanthanide complexation with $\mathrm{Lu}^{3+}, \mathrm{Ho}^{3+}$ and $\mathrm{Tm}^{3+}$ ). The peptide sequence marking locations are shown by an asterisk. 
NOTE: ${ }^{1} \mathrm{~A}$ underlined letter C: reduced-SH with MMTS.

${ }^{2}$ The underlined values refer to the $\mathrm{m} / \mathrm{z}$ signals identified

by MALDI MS

82

Table 10. Identified proteins from fish bile

Table 11. Significant Spearman correlations for bile

in the control group

Table 12. Significant Spearman correlations for liver

in the control group

Table 13. Significant Spearman correlations for liver in the $\mathrm{Ni}$-exposed group

Table 14. Significant Spearman correlations for bile in the $\mathrm{Zn}$-exposed group

Table 15. Significant Spearman correlation for liver in the Zn-exposed group

Table 16. Normalized importance for each variable for both bile and liver in the $\mathrm{Ni}$-exposed group

Table 17. Normalized importance for each variable for both bile and liver in the $\mathrm{Zn}$-exposed group 